\title{
Persepsi Pemustaka terhadap Pemanfaatan Perpustakaan Perguruan Tinggi: Sebuah Analisis Korelasi
}

\author{
Uminurida Suciati* \\ Dwi Rahayu* \\ Universitas Gadjah Mada, Yogyakarta
}

\begin{abstract}
Abstrak
Penelitian ini mengeksplorasi persepsi pemustaka dalam memanfaatkan perpustakaan perguruan tinggi dalam hal ini universitas, dan korelasi antara persepsi pemustaka dan pemanfaatan perpustakaan. Hasil temuan menunjukkan bahwa perpustakaan universitas merupakan tempat yang menjadi pilihan untuk belajar dan menghabiskan waktu selama tidak ada perkuliahan di kampus. Kegiatan pemustaka di perpustakaan sering digunakan untuk hal-hal tertentu, termasuk studi individu, membaca, penggunaan komputer, mencari informasi, belajar kelompok, menggunakan layanan referensi dan informasi, dan pertemuan juga diskusi kelompok dan bersosialisasi. Korelasi antara penggunaan perpustakaan dan masing-masing kegiatan pemustaka diamati. Hasil temuan menunjukkan bahwa pemustaka menganggap perpustakaan universitas, sebagai tempat untuk belajar dan mencari informasi. Studi ini menunjukkan bagaimana pemustaka memandang dan menggunakan perpustakaan universitas dapat memperkuat, memberikan wawasan ke dalam proses pembelajaran, menumbuhkan enterpreneurship, dan memajukan peran pemustaka dalam komunitas akademis.
\end{abstract}

Kata kunci: Perpustakaan Universitas, pemustaka, persepsi pemustaka 


\begin{abstract}
This study explores the perception of users in utilizing the college library in this university and the correlation between the perception of the user and the utilization of the library. The findings show that university libraries are the preferred place to study and spend as long as there are no lectures on campus. Library activity is often used for certain things, including individual studies, reading, computer use, information seeking, group learning, reference, and information services, and group meetings and group discussions and socializing. The correlation between the use of libraries and each observation activity is observed. The findings show that the librarian considers the university library, as a place to learn and seek information. This study shows how viewers view and use university libraries can strengthen, provide insight into the learning process, foster entrepreneurship, and advance user roles in the academic community.
\end{abstract}

Keywords: University library, library, perception of user

\title{
Pengantar
}

Perpustakaan perguruan tinggi telah memainkan peran penting di kampus sebagai “jantung universitas." Sebagai upaya untuk memajukan di kalangan akademisi, perpustakaan telah mengakomodasi perubahan dalam tren pemanfaatan fasilitas untuk mendukung pemustaka dengan lebih baik dalam proses belajar dan pencarian sumber informasi sebagai karya intelektual. Perubahan yang terjadi dalam pendekatan pemustaka terhadap pencarian informasi dan pembelajaran telah membawa kebutuhan akan transisi di sisi fasilitas dan layanan perpustakaan. Perpustakaan akademis telah memanfaatkan teknologi baru dan mendesain ulang layanan untuk mengakomodasi perubahan dalam memenuhi kebutuhan dan perilaku pemustaka. Meski informasi yang luas tersedia dari jarak jauh, perpustakaan secara fisik masih menjadi pilihan bagi pemustaka (Applegate ${ }^{1}$, 2009). Berbagai penelitian telah melaporkan peningkatan penggunaan fasilitas

\footnotetext{
${ }^{1}$ Applegate, R. (2009). The library is for studying: Student preferences for study space. Journal of Academic Librarianship, 35, 341-346.
} 
perpustakaan (Houlihan ${ }^{2}$, 2005; McKay $^{3}$, 2011; Shill ${ }^{4} \&$ Tonner, 2004). Peneliti menyebut peningkatan tersebut sebagai "mental pasca internet" (Albanese ${ }^{5}$, 2003).

Perpustakaan perguruan tinggi masih menjadi salah satu tempat yang paling banyak dikunjungi mahasiswa di kampus. Perpustakan mendukung berbagai aktivitas pemustaka untuk mencari informasi, studi individu dan kelompok, sosialisasi, dan relaksasi. Karena semakin banyak aspek pembelajaran sosial dan kolaboratif yang ditekankan pada pendidikan tinggi, perpustakaan perguruan tinggi telah berkembang menjadi pusat kegiatan sosial serta pusat-pusat sumber informasi karya intelektual. Perpustakaan perguruan tinggi akan menyesuaikan dengan tren aktivitas akademis dan sosial pemustaka dan akan terus berfungsi sebagai institusi penting di dalam masyarakatnya. Dengan demikian, perpustakaan perguruan tinggi harus melakukan upaya terus menerus untuk menyediakan fasilitas dan layanan berbasis pemustaka berdasarkan pada pemahaman kebutuhan dan perilaku pemustaka. Menangkap perubahan persepsi dan perilaku pemustaka merupakan bagian yang sangat penting dalam merencanakan fasilitas dan layanan perpustakaan.

Mengingat pentingnya perpustakaan perguruan tinggi di institusi akademis dan sifat perubahan persepsi dan perilaku pemustaka, sangat penting untuk menguji persepsi pemustaka perpustakaan akademis dan bagaimana kaitannya dengan pemanfaatan perpustakaan. Studi ini mengeksplorasi persepsi pemustaka dan pemanfaatan perpustakaan perguruan tinggi melalui survei. Survei ini menyelidiki persepsi pemustaka, pola pemanfaatan, dan korelasi persepsi pemustaka dan pemanfaatan fasilitas perpustakaan. Studi empiris tentang persepsi pemustaka dan perilaku

${ }^{2}$ Houlihan, R. (2005). The academic library as congenial space: More on the Saint Mary's experience. New Library World, 106(1208/1209), 7-15.

${ }^{3}$ McKay, D. (2011). Spinning straw into gold: A community college library's twenty first century transformation. Community \& Junior College Libraries, 17, 1-6.

${ }^{4}$ Shill, H. B., \& Tonner, S. (2004). Does the building still matter? Usage patterns in new, expanded, and renovated libraries, 1995-2002. College \& Research Libraries, 65, 123-150.

${ }^{5}$ Albanese, A. R. (2003). Deserted no more. Library Journal, 128, 34-36. 
pemanfaatan dapat memberikan wawasan mengenai peningkatan keputusan manajemen dalam merencanakan fasilitas dan layanan perpustakaan.

\section{Tinjauan Literatur}

Beberapa penelitian telah melaporkan statistik pemanfaatan dan preferensi pemustaka perpustakaan perguruan tinggi. Suciati ${ }^{6} \mathrm{dkk}$ (2012) dalam penelitiannya mengungkapkan preferensi pemustaka dalam menyusun tugas akhir studi lebih menyukai menggunakan buku teks cetak daripada e-book dan e-journal, pada masa itu. Dalam sebuah studi yang membandingkan pola penggunaan fasilitas pra-proyek dan pasca-penyelesaian untuk proyek fasilitas perpustakaan, sebagian besar institusi yang menyelesaikan proyek fasilitas perpustakaan melaporkan peningkatan penggunaan secara keseluruhan (Shill \& Tonner7, 2004). Fitur fasilitas khusus yang terkait dengan peningkatan penggunaan meliputi kualitas laboratorium, jenis institusi, tata letak, jumlah port data, workstation akses publik, pencahayaan alami, ruang kerja pemustaka, infrastruktur telekomunikasi, dan suasana keseluruhan. Studi tersebut memberikan bukti empiris bahwa mahasiswa akan menggunakan perpustakaan yang nyaman dan dilengkapi dengan baik meskipun ada sumber elektronik yang tersedia dari jarak jauh. Temuan menunjukkan bahwa perpustakaan yang dirancang dengan baik akan menarik minat mahasiswa sebagai tempat belajar dan bersosialisasi dan tetap penting bagi komunitas akademis. Martell ${ }^{8}$ (2008) melaporkan kenaikan jumlah akses dan penggunaan sumber daya jaringan elektronik dalam sebuah penelitian yang menyediakan data tentang penggunaan perpustakaan sejak tahun 1990an sampai 2006 di University of South Carolina.

${ }^{6}$ Suciati, Uminurida; Nurhayati; Widayati, Preferensi Pemustaka dalam Menyusun Tugas Akhir (skripsi/Tesis/Disertasi) Menggunakan Sumber Informasi Database Online (studi kasus di Perpustakaan Fakultas Filsafat UGM), Berkala Ilmu Perpustakaan dan Informasi Vol. 7 no 1 tahun 2012,, Perpustakaan UGM

${ }^{7}$ Shill, H. B., \& Tonner, S. (2004). Does the building still matter? Usage patterns in new, expanded, and renovated libraries, 1995-2002. College \& Research Libraries, 65, 123-150.

${ }^{8}$ Martell, C. (2008). The absent user: Physical use of academic library collections and services continues to decline 1995-2006. Journal of Academic Librarianship, 34, 400-407. 
Secara khusus, terjadi peningkatan penggunaan layanan yang dapat dimanfaatkan secara gratis oleh pemustaka. Layanan diantaranya beberapa akses sumber informasi yang dapat diakses di internet dan peminjaman koleksi cetak, dan komputer katalog. Karena studi pemanfaatan bangunan menunjukkan penggunaan ruang belajar yang tinggi, terutama di Perpustakaan Universitas Gadjah Mada membuat lebih banyak ruang untuk kelompokkelompok belajar dan tempat duduk berkelompok. Hal ini mengakibatkan peningkatan pemanfaatan fungsi ruang, menunjukkan bahwa mahasiswa menginginkan ruang belajar. Survei bangunan memberi kesempatan perpustakaan untuk memeriksa pemanfaatan fasilitas perpustakaan dan preferensi pemustaka mengenai sumber daya perpustakaan, layanan, dan ruang. Applegate $^{9}$ (2009) memeriksa preferensi mahasiswa untuk ruang belajar dan menemukan bahwa perpustakaan merupakan tempat yang disukai untuk kegiatan akademik yang tidak segera terhubung dengan sesi tatap muka kelas (ruang perkuliahan). Ruang studi yang paling disukai di perpustakaan universitas yakni ruang belajar diskusi, yang menyiratkan bahwa mahasiswa mungkin lebih suka bila diijinkan untuk berbicara sambil belajar di perpustakaan. Penelitian penggunaan meja belajar carrel secara tradisional tampaknya memiliki daya tarik, menunjukkan peningkatan penggunaan selama satu semester. Akses internet nirkabel dan outlet listrik juga dianggap sebagai elemen penting bagi pengguna laptop. Mengingat hal ini, Waxman ${ }^{10}$ (2007) meneliti persepsi akademis fakultas dan pustakawan mengenai disain dan ketersediaan ruang kampus. Studi ini mengidentifikasi kebutuhan untuk menyambut pemustaka dengan ruang-ruang belajar di kampus guna mendukung kegiatan informasi dan pembelajaran mahasiswa. Di perpustakaan UGM pemanfaatan selasar, lorong-lorong penghubung menjadi bagian yang tidak terpisahkan dengan kebutuhan tempat belajar. Pemustaka dan pustakawan perguruan tinggi mencatat bahwa kursi yang

\footnotetext{
${ }^{9}$ Applegate, R. (2009). The library is for studying: Student preferences for study space. Journal of Academic Librarianship, 35, 341-346.

${ }^{10}$ Waxman, L., Clemons, S., Banning, J., \& McKelfresh, D. (2007). The library as place: Provid- ing students with opportunities for socialization, relaxation, and restoration. New Library World, 108, 424-434.
} 
empuk, meja yang luas, workstation ergonomis, permukaan lantai yang bersih, dan detail estetika merupakan elemen sambutan untuk mendukung kinerja pembelajaran akademis. Mereka juga menekankan pentingnya memberi mahasiswa ruang sosial untuk kolaborasi, berbagi informasi, dan down-time dengan teman sebayanya.

Peterson $^{11}$ (2005) mengidentifikasi lima jenis aktivitas pemustaka di mana ruang perpustakaan harus dirancang sebagai: ruang pencarian informasi, ruang rekreasi, ruang pengajaran dan pembelajaran, ruang koneksi, dan ruang kontemplasi (renungan dan sebagainya dengan kebulatan pikiran atau perhatian penuh). Dijelaskan bahwa ruang perpustakaan harus mengakomodasi aktivitas pemustaka untuk mencari berbagai informasi untuk pekerjaan dan kehidupan pribadi, dan mendukung pemustaka yang mencari materi/bahan relaksasi/hiburan atau kegiatan untuk tujuan rekreasi. Ruang belajar mengajar juga diperlukan untuk mendukung kegiatan seperti belajar kelompok, kelas, pengajaran dan pembelajaran satu lawan satu, kursus, kegiatan keberaksaraan, pelatihan, dan bantuan pekerjaan rumah. Untuk koneksi, perpustakaan berfungsi sebagai ruang pertemuan komunal bagi mereka yang memiliki kegiatan akademis, sosial, komunitas, dan budaya. Bagi mereka yang membutuhkan ruang diam/tenang, perpustakaan berfungsi sebagai tempat tenang, sunyi, senyap dan tempat yang ditunjuk untuk kontemplasi.

Suciati $^{12}$ (2015) menjelaskan beberapa mahasiswa program doktor lebih menyukai tempat belajar yang tenang, untuk fokus pada naskah disertasinya diperlukan ruang khusus. Ruang belajar mandiri di Perpustakaan UGM dapat digunakan sebagai ruang "bertapa" bagi pemustaka yang ingin cepat selesai tugas akhirnya. Keheningan dalam belajar di ruang mandiri apabila terusik oleh suara sekelompok pemustaka yang belajar pun akan menjadi perhatian dan pandangan sebagai teguran bahwasanya zona tempat berada merupakan zona tenang.

${ }^{11}$ Peterson, C. A. (2005). Space designed for lifelong learning: The Dr. Martin Luther King Jr. Joint-use Library. Library as place: Rethinking roles, rethinking space (pp. 56-65). Washington, D.C.: Council on Library and Information Resources.

${ }^{12}$ Suciati, Uminurida (2015). Evaluasi pemanfaatan fasilitas belajar ruang diskusi tahun 2015. Yogyakarta: Perpustakaan UGM. 
Berbagai penelitian telah meneliti hubungan antara karakteristik pemustaka dan pola pemanfaatan perpustakaan perguruan tinggi. Dalam sebuah penelitian yang berfokus pada apakah pemanfaatan perpustakaan perguruan tinggi pada tahun-tahun pertama dikaitkan dengan karakteristik sosial ekonomi mahasiswa. Soria, Nackerud, dan Peterson ${ }^{13}$ (2015) menemukan bahwa penggunaan perpustakaan perguruan tinggi oleh mahasiswa dikaitkan dengan beragam indikator sosio ekonomi. Temuan menunjukkan bahwa mahasiswa dari latar belakang status sosial ekonomi yang lebih rendah cenderung menggunakan perpustakaan di berbagai unit layanan seperti sirkulasi, layanan referensi, mengakses e-book dan e-journal, dan menggunakan workstation perpustakaan. Whitmire ${ }^{14}$ (2003) meneliti apakah ada perbedaan dalam penggunaan perpustakaan akademik oleh mahasiswa di kalangan suku atau ras. Ada kesamaan di antara kelompok suku/ras dalam hal frekuensi aktivitas perpustakaan di mana mahasiswa terlibat, namun perbedaan ditemukan pada frekuensi aktivitas seperti menemukan materi saat melihat-lihat tumpukan koleksi cetak, memeriksa kutipan, dan memeriksa buku. Ada juga perbedaan faktor yang terkait dengan pemanfaatan perpustakaan akademis di berbagai kelompok ras yang beragam. Hall dan Kapa ${ }^{15}$ (2015) menyelidiki kebutuhan spesifik dari komunitas kampus perpustakaan dan menemukan perbedaan dalam pemanfaatan perpustakaan oleh pemustaka dari berbagai program studi. Studi tersebut melaporkan bahwa hanya 35\% responden yang datang ke perpustakaan untuk meminjam materi, sedangkan $84 \%$ mengunjungi perpustakaan untuk menggunakan ruang belajar. Juga ditemukan bahwa mahasiswa yang menggunakan titik layanan paling sering tidak selalu mereka yang paling banyak menggunakan ruang belajar. Bridges ${ }^{16}$ (2008) meneliti

\footnotetext{
${ }^{13}$ Peterson, C. A. (2005). Space designed for lifelong learning: The Dr. Martin Luther King Jr. Joint-use Library. Library as place: Rethinking roles, rethinking space (pp. 56-65). Washington, D.C.: Council on Library and Information Resources.

${ }^{14}$ Whitmire, E. (2003). Cultural diversity and undergraduates' academic library use. Journal of Academic Librarianship, 29, 148-161.

${ }^{15}$ Hall, K., \& Kapa, D. (2015). Silent and independent: Student use of academic library study space. Canadian Journal of Library and Information Practice and Research, 10(1), 1-38.

${ }^{16}$ Bridges, L. M. (2008). Who is not using the library? A comparison of undergraduate academic disciplines and library use. Portal: Libraries and the Academy, 8, 187-196.
} 
perbedaan penggunaan perpustakaan fisik mahasiswa dan perpustakaan virtual dengan disiplin akademik dan kelas berdiri. Studi ini menemukan perbedaan yang signifikan dalam penggunaan perpustakaan fisik dan perpustakaan virtual dengan disiplin akademik. Namun, tidak ada perbedaan signifikan yang ditentukan dalam penggunaan perpustakaan fisik dan perpustakaan virtual berdasarkan kelas. Beberapa penelitian telah meneliti hubungan antara pemanfaatan perpustakaan dan kinerja akademis untuk menunjukkan dampak positif perpustakaan akademik pada komunitas akademik. Dalam sebuah penelitian yang diselidiki korelasi antara penggunaan perpustakaan mahasiswa dan kinerja akademis mereka, Wong dan Webb ${ }^{17}$ (2011) menemukan korelasi positif antara pinjaman buku mahasiswa dan rata-rata nilai kumulatif (IPK) mereka. Hasilnya menunjukkan bahwa perpustakaan akademik memegang peranan penting dalam keberhasilan belajar dan akademik mahasiswa. De Jager $^{18}$ (1997) juga melaporkan bahwa siswa dengan prestasi akademis yang lebih baik cenderung menggunakan lebih banyak materi perpustakaan daripada kelas dengan nilai rendah. Dalam sebuah penelitian yang menganalisis hubungan antara pemanfaatan perpustakaan dan kinerja akademis, Allison ${ }^{19}$ (2015) menemukan korelasi antara pemanfaatan perpustakaan akademik dan peningkatan IPK yang lebih besar. Penelitian ini juga menemukan bahwa pemanfaatan perpustakaan berkorelasi dengan retensi siswa, memberikan bukti bahwa perpustakaan memainkan peran positif dalam kinerja siswa dan adaptasi ke sekolah. Soria, Fransen, dan Nackerud ${ }^{20}$ (2014) menemukan bahwa mahasiswa sarjana pertama yang memanfaatkan perpustakaan memiliki IPK yang lebih tinggi dan tingkat retensi yang lebih tinggi daripada mereka yang tidak menggunakan perpustakaan. Khususnya, area pemanfaatan perpustakaan,

${ }^{17}$ Wong, S. H. R., \& Webb, T. D. (2011). Uncovering meaningful correlation between student academic performance and library material usage. College \& Research Libraries, 72, 361-370.

${ }^{18}$ de Jager, K. (1997). Library use and academic achievement. South African Journal of Library \& Information Science, 65, 26-30.

${ }^{19}$ Allison, D. (2015). Measuring the academic impact of libraries. Portal: Libraries and the Academy, 15, 29-40.

${ }^{20}$ Soria, K. M., Fransen, J., \& Nackerud, S. (2014). Stacks, serials, search engines, and students' success: First-year undergraduate students' library use, academic achieve- ment, and retention. Journal of Academic Librarianship, 40, 84-91. 
termasuk login database, pinjaman buku, dan login jurnal elektronik, secara positif terkait dengan IPK dan retensi siswa. Temuan tersebut menyiratkan bahwa pemanfaatan perpustakaan meningkatkan akses mahasiswa terhadap sumber daya akademis dan meningkatkan kompetensi mereka dalam bidang akademik, sehingga menghasilkan prestasi akademik yang lebih tinggi.

Beberapa penelitian melaporkan adanya hubungan positif antara pemanfaatan perpustakaan dan kinerja akademis, yang menunjukkan peran penting perpustakaan akademik dalam keberhasilan akademis siswa. Dari survei tersebut diperoleh informasi tentang pemanfaatan perpustakaan universitas oleh responden, termasuk pertanyaan tentang tempat mana yang lebih disukai. Belajar dan membaca, tempat mana yang lebih suka menghabiskan waktu di masa selesai kuliah di kampus, seberapa sering mereka mengunjungi perpustakaan universitas, dan berapa lama rata-rata mereka tinggal di perpustakaan pada setiap kunjungan ke perpustakaan. Selain itu, frekuensi kegiatan yang dilakukan responden di perpustakaan diukur dengan menggunakan skala Likert 7 poin. Untuk mengeksplorasi hubungan antara pemanfaatan perpustakaan fisik dan penggunaan situs perpustakaan, bagian kedua dari survei tersebut mencakup pertanyaan tentang pemanfaatan situs perpustakaan universitas oleh responden. Ini termasuk pertanyaan tentang apakah mereka pernah mengunjungi situs web perpustakaan, seberapa sering mereka mengunjungi situs web, dan layanan apa di situs web perpustakaan yang paling sering mereka gunakan. Bagian ketiga mencakup pertanyaan tentang persepsi responden terhadap perpustakaan akademik. Peserta penelitian diminta untuk menunjukkan tempat yang mereka anggap sebagai tempat belajar paling nyaman di perpustakaan universitas. Item tersebut diajukan berdasarkan penjelasan Peterson $^{21}$ (2005) tentang jenis aktivitas pemustaka yang harus dirancang oleh perpustakaan. Dalam penelitian ini, responden diminta untuk menunjukkan seberapa kuat mereka menyetujui masing-masing item yang menggambarkan

${ }^{21}$ Peterson, C. A. (2005). Space designed for lifelong learning: The Dr. Martin Luther King Jr. Joint-use Library. Library as place: Rethinking roles, rethinking space (pp. 56-65). Washington, D.C.: Council on Library and Information Resources. 
perpustakaan universitas sebagai tempat mencari informasi, belajar, bertemu dan bersosialisasi, rekreasi, atau kontemplasi. Item diberi nilai pada skala Likert 7 poin $(1=$ sangat tidak setuju, $2=$ sedikit tidak setuju, $3=$ sedikit tidak setuju, $4=$ netral, $5=$ sedikit setuju, $6=$ cukup setuju, dan $7=$ sangat setuju). Bagian terakhir dari survei tersebut meminta informasi mengenai informasi demografis responden.

\section{Prosedur}

Studi ini dilakukan di kampus Universitas Gadjah Mada pada bulan Februari 2016. Kampus ini melayani mahasiswa vokasi, program sarjana dan pascasarjana, sedangkan data statistik pada tahun 2016, ada sebanyak 206.403 kunjungan mahasiswa, ini tidak termasuk tamu yang berkunjung dari luar kota. Perpustakaan universitas terletak di tengah-tengah kampus, sehingga dapat dikatakan sebagai jantungnya universitas. Terdiri atas 4 gedung yang terhubung satu dengan yang lain meliputi 3 dan 4 lantai. Fasilitas perpustakaan menyediakan peralatan dan area studi termasuk ruang belajar kelompok, belajar carrel/individu, ruang baca, ruang diskusi, ruang pertemuan, ruang telekonference, dan ruang belajar. Penelitian ini terletak pada penelitian akademis yang lebih luas yang bertujuan untuk memahami persepsi pemustaka perpustakaan akademik.

Pengumpulan data dimulai dengan membagikan kuesioner secara pribadi kepada pemustaka di lobi di depan perpustakaan universitas dari pukul 09.00 sampai 16.00 pada tanggal 2 dan 3 pada bulan Februari 2016. Lobi yang terletak di lantai pertama perpustakaan pusat, merupakan pintu masuk utama perpustakaan dilanjutkan di sekitar ruang belajar mandiri, diskusi, referensi, ruang layanan koleksi lainnya yang ada fasilitas belajar dan gazebo di depan gedung dan di taman bagian dalam. Responden yang memiliki pengalaman menggunakan perpustakaan universitas diminta mengisi kuesioner. Sebuah pertanyaan skrining diminta untuk meyakinkan bahwa responden memiliki pengalaman menggunakan fasilitas perpustakaan universitas. Partisipasi bersifat sukarela, dan responden yang keberatan tidak kami paksa untuk mengisi kuesioner. Dari 225 kuesioner yang disebarkan, 
sebanyak 220 kuesioner diterima. Setelah membuang tanggapan kuesioner yang tidak lengkap, 206 tanggapan dianalisis dengan menggunakan statistik deskriptif. Semua analisis statistik dilakukan dengan menggunakan analisis korelasi SPSS versi 22.0. Spearman dilakukan untuk menganalisis korelasi pemanfaatan perpustakaan akademik dan persepsi pemustaka.

Statistik deskriptif dihitung untuk karakteristik responden. Mayoritas responden adalah mahasiswa S0 (18\%), mahasiswa S1 (47,6,7\%), mahasiswa S2 $(24,8 \%)$, dan mahasiswa S3 $(9,7)$. Interval jenis kelamin yakni $63,1 \%$ responden perempuan, dan 36,9\% laki-laki. Mengenai tempat tinggal, mayoritas responden tinggal di luar kampus $(80,6 \%)$, sementara sebagian kecil responden tinggal di dekat kampus $(19,4 \%)$.

\section{Fasilitas Belajar Yang Dimiliki}

Untuk mengidentifikasi tempat mana yang lebih disukai oleh responden untuk belajar atau menghabiskan waktu di kampus, preferensi pemustaka dilakukan pemeriksaan dan observasi. Mengenai tempat yang disukai untuk dipelajari dan dibaca, responden diminta untuk menunjukkan tiga item dan memberi peringkat sesuai dengan prioritas mereka. Untuk yang pertama preferensi/disukai tempat untuk belajar dan membaca, sejumlah besar responden mengindikasikan perpustakaan (34\%), rumah $(29,6 \%)$ diikuti oleh kafe (7,3\%), ruang kelas/kuliah (9,7 \%), laboratorium (9,3\%), asrama/kos (5,3\%), taman/kebun (4,9\%) dan sisa responden menunjukkan lainnya $(1,9 \%)$ sebagai tempat pilihan pertama mereka. Untuk tempat kedua yang disukai untuk belajar, sejumlah besar responden menunjukkan rumah $(32,5 \%)$, perpustakaan $(27,2 \%)$ diikuti, ruang kelas $(6,3 \%)$, kafe $(13,1 \%)$, laboratorium $(9,2 \%)$, taman/kebun (6,3\%), dan lainnya (1\%).

Tabel 1. Preferensi belajar mahasiswa di Perpustakaan UGM tahun 2016

\begin{tabular}{lcccccc}
\hline \multirow{2}{*}{ Tempat } & \multicolumn{2}{c}{ Preferensi pertama } & \multicolumn{2}{c}{ Preferensi kedua } & \multicolumn{2}{c}{ Preferensi Ketiga } \\
\cline { 2 - 7 } & Frek & Persentasi & Frek & Persentasi & Frek & Persentasi \\
\hline Rumah & 61 & 29,6 & 67 & 32,5 & 43 & 20,9 \\
\hline Perpustakaan & 70 & 34,0 & 56 & 27,2 & 52 & 25,2 \\
\hline
\end{tabular}




\begin{tabular}{lcccccc}
\hline \multirow{2}{*}{ Tempat } & \multicolumn{2}{c}{ Preferensi pertama } & \multicolumn{2}{c}{ Preferensi kedua } & \multicolumn{2}{c}{ Preferensi Ketiga } \\
\cline { 2 - 7 } & Frek & Persentasi & Frek & Persentasi & Frek & Persentasi \\
\hline Cafe/Restoran & 15 & 7,3 & 27 & 13,1 & 13 & 6,3 \\
\hline Ruang Kuliah & 20 & 9,7 & 13 & 6,3 & 62 & 30,1 \\
\hline Laboratorium & 15 & 7,3 & 19 & 9,2 & 10 & 4,9 \\
\hline Asrama/Kos & 11 & 5,3 & 9 & 4,4 & 12 & 5,8 \\
\hline Taman/Kebun & 10 & 4,9 & 13 & 6,3 & 14 & 6,8 \\
\hline Lainnya & 4 & 1,9 & 2 & 1,0 & 0 & 0,0 \\
\hline Total & 206 & 100,0 & 206 & 100,0 & 206 & 100,0 \\
\hline
\end{tabular}

Data diolah 2017

Berdasarkan tabel satu nampak bahwa perpustakaan mendominasi preferensi pemustaka sebagai tempat belajar. Mengingat tempat yang disukai untuk menghabiskan waktu selama waktu tidak ada jam perkuliahan di kampus, responden diminta untuk menunjukkan tiga item dan memberi peringkat sesuai prioritas mereka. Tempat yang paling disukai untuk menghabiskan waktu di masa tidak ada jam perkuliahan di kampus yakni rumah $(31,6 \%)$, perpustakaan $(28,2 \%)$, diikuti oleh kafe $(15,5 \%)$, kemudian ruang kelas dan laboratorium sama (4,9\%), asrama/kos $(7,8 \%)$, taman terbuka $(2,9 \%)$ dan sisa responden menunjukkan lainnya $(4,4 \%)$ sebagai tempat pilihan pertama mereka. Untuk tempat kedua yang disukai untuk belajar, sejumlah besar responden menunjukkan rumah $(37,9 \%)$, perpustakaan $(24,8 \%)$, diikuti oleh kafe $(19,4 \%)$, kemudian kelas $(4,4 \%)$, laboratorium $(3,9 \%)$, asrama/kos $(4,4 \%)$, taman terbuka $(2,9 \%)$ dan sisa responden menunjukkan lainnya $(2,4 \%)$.

Tabel 2. Preferensi mahasiswa menghabiskan waktu setelah kuliah 2016

\begin{tabular}{lcccccc}
\hline \multirow{2}{*}{ Tempat } & \multicolumn{2}{c}{ Preferensi pertama } & \multicolumn{2}{c}{ Preferensi kedua } & \multicolumn{2}{c}{ Preferensi Ketiga } \\
\cline { 2 - 7 } & Frek & Persentasi & Frek & Persentasi & Frek & Persentasi \\
\hline Rumah & 65 & 31,6 & 78 & 37,9 & 56 & 27,2 \\
\hline Perpustakaan & 58 & 28,5 & 51 & 24,8 & 61 & 29,6 \\
\hline Cafe/Restoran & 32 & 15,5 & 40 & 19,4 & 41 & 19,9 \\
\hline Ruang Kuliah & 10 & 4,9 & 9 & 4,4 & 12 & 5,8 \\
\hline
\end{tabular}




\begin{tabular}{lcccccc}
\hline \multirow{2}{*}{ Tempat } & \multicolumn{2}{c}{ Preferensi pertama } & \multicolumn{2}{c}{ Preferensi kedua } & \multicolumn{2}{c}{ Preferensi Ketiga } \\
\cline { 2 - 7 } & Frek & Persentasi & Frek & Persentasi & Frek & Persentasi \\
\hline Laboratorium & 10 & 4,9 & 8 & 3,9 & 13 & 6,3 \\
\hline Asrama/Kos & 16 & 7,8 & 9 & 4,4 & 11 & 5,3 \\
\hline Taman & 6 & 2,9 & 6 & 2,9 & 5 & 2,4 \\
\hline Lainnya & 9 & 4,4 & 5 & 2,4 & 7 & 3,4 \\
\hline Total & 206 & 100,0 & 206 & 100,0 & 206 & 100,0 \\
\hline
\end{tabular}

Data diolah 2017

\section{Jangka Waktu Pemanfaatan Perpustakaan}

Untuk mengeksplorasi keseluruhan pola pemanfaatan responden di perpustakaan universitas, frekuensi kunjungan perpustakaan dan rata-rata waktu setiap kunjungan dianalisis (lihat Tabel 3).

\section{Tabel 3 Pemanfaatan fasilitas Perpustakaan UGM tahun 2016}

\begin{tabular}{lrr}
\hline Pemanfaatan perpustakaan akademik $(\mathrm{n}=206)$. & & \\
\hline \multicolumn{1}{c}{ Kunjungan Penggunaan perpustakaan } & Frekuensi & presentasi \\
\hline Hampir setiap hari & 87 & 42,2 \\
\hline Beberapa kali seminggu & 65 & 31,6 \\
\hline Beberapa kali sebulan & 24 & 11,7 \\
\hline Sekali sebulan & 15 & 7,3 \\
\hline Beberapa kali setahun & 10 & 4,9 \\
\hline Kira-kira setahun sekali & 5 & 2,4 \\
\hline Jarang & 206 & 100,0 \\
\hline
\end{tabular}

Lama waktu yang digunakan rata-rata setiap kunjungan ke perpustakaan

\begin{tabular}{|c|c|c|}
\hline Kurang dari satu jam & 23 & 11,2 \\
\hline Satu sampai dua jam & 62 & 30,1 \\
\hline Dua sampai empat jam & 98 & 47,6 \\
\hline Empat sampai enam jam & 15 & 7,3 \\
\hline Lebih dari enam jam & 8 & 3,9 \\
\hline & 206 & 100,0 \\
\hline
\end{tabular}

Data diolah 2017 
Mengenai frekuensi kunjungan perpustakaan, sejumlah besar responden melaporkan mengunjungi perpustakaan beberapa kali dalam seminggu $(31,6 \%)$, hampir setiap hari $(42,2 \%)$, atau beberapa kali dalam sebulan $(11,7 \%)$. Sisa responden melaporkan mengunjungi perpustakaan agak jarang: sekitar sekali sebulan $(7,3 \%)$, jarang $(2,4 \%)$, atau beberapa kali dalam setahun (4,9\%). Mengenai pertanyaan berapa lama rata-rata mereka tinggal di perpustakaan pada setiap kunjungan, sejumlah besar responden melaporkan tinggal selama dua sampai empat jam (47,6\%) atau satu sampai dua jam $(30,1 \%)$. Sisa responden melaporkan tinggal kurang dari satu jam $(11,2 \%)$, empat sampai enam jam (7,3\%), atau lebih dari enam jam (3,9\%).

Untuk mengidentifikasi penggunaan situs web perpustakaan, frekuensi situs perpustakaan dikunjungani dan layanan yang sering digunakan di situs web dianalisis. Responden diminta untuk menunjukkan apakah mereka pernah mengunjungi situs web perpustakaan. Sejumlah besar responden $(64,4 \%)$ melaporkan bahwa mereka telah mengunjungi situssitus perpustakaan, di mana 35,6\% lainnya melaporkan bahwa mereka tidak mengunakan situs web perpustakaan. Mengenai frekuensi kunjungan situs perpustakaan, sejumlah besar responden mengindikasikan mengunjungi situs web perpustakaan beberapa kali dalam sebulan $(31,1 \%)$, beberapa kali seminggu (27,7\%), hampir setiap hari $(13,4 \%)$, atau sekitar Sebulan sekali $(13,4 \%)$. Sisa responden menunjukkan 'beberapa kali dalam setahun' $(8,4 \%)$, 'jarang' (5,0\%), atau 'sekitar setahun sekali' (0,8\%). Mengenai layanan yang sering digunakan di situs perpustakaan, responden diminta memilih dua koleksi di antara jenis koleksi yang disediakan. Persentase terbesar responden menunjukkan sumber daya elektronik (e-book, e-journal, database, dan konten e-learning) (51,7\%), diikuti dengan mencari katalog perpustakaan dan meminjam (28,2\%), informasi perpustakaan (jam, lokasi, kebijakan perpustakaan, dll.) $(14,7 \%)$, meminta pustakawan $(1,2 \%)$, dukungan TI $(2,5 \%)$, dan lainnya $(1,7 \%)$.

Analisis korelasi Spearman dilakukan untuk mengeksplorasi korelasi pola penggunaan perpustakaan fisik dan situs web perpustakaan. Korelasi positif yang signifikan ditemukan antara frekuensi kunjungan perpustakaan 
dan waktu rata-rata setiap kunjungan ke perpustakaan $(\mathrm{r}=0,39, \mathrm{p} \mathrm{b} 0,01)$. Juga ditemukan bahwa ada korelasi positif yang signifikan antara frekuensi kunjungan perpustakaan dan frekuensi kunjungan situs perpustakaan ( $\mathrm{r}$ $=0,29, \mathrm{p}$ b 0,01). Namun, tidak ada korelasi yang signifikan antara lama waktu rata-rata setiap kunjungan ke perpustakaan secara fisik dan frekuensi kunjungan situs web perpustakaan ( $\mathrm{p} \mathrm{N} \mathrm{0,05).}$

\section{Kegiatan Pemustaka dalam Perpustakaan}

Mengenai kegiatan yang dilakukan pemustaka saat berada di perpustakaan akademik, responden diminta untuk menunjukkan frekuensi melakukan aktivitas setiap kegiatan juga menggunakan skala Likert 7 poin ( $1=$ sangat jarang, 2 = cukup jarang, $3=$ agak jarang , $4=$ netral, $5=$ agak sering, $6=$ cukup sering, dan $7=$ sangat sering). Berikut ini tabel yang menyajikan sarana standar deviasi frekuensi aktivitas pemustaka, diantaranya belajar mandiri, membaca, menggunakan komputer, mencari informasi, belajar kelompok (diskusi), menggunakan layanan referensi dan informasi, menggunakan untuk rapat/pertemuan, sosialisasi, layanan sirkulasi, diperbolehkan makan \& minum, ada pelatihan, menggunakan bahan audio visual, workshop/seminar, ikut berpartisipasi dalam event kegiatan perpustakaan.

Tabel 4 Menyajikan sarana dan standar deviasi frekuensi aktivitas pemustaka

\begin{tabular}{lcc}
\hline \multicolumn{3}{c}{ Frekuensi aktivitas pemustaka di Perpustakaan } \\
\hline Aktivitas & Mean & Standard deviation \\
\hline Belajar mandiri & 5.23 & 1.75 \\
\hline Membaca & 5.17 & 1.68 \\
\hline Menggunakan komputer & 5.11 & 1.84 \\
\hline Mencari informasi & 4.48 & 1.76 \\
\hline Belajar Kelompok (diskusi) & 4.22 & 1.92 \\
\hline Menggunakan layanan referensi \& informasi & 3.75 & 1.86 \\
\hline Pertemuan/rapat \& sosialisasi & 3.51 & 1.81 \\
\hline Layanan Sirkulasi & 3.42 & 1.74 \\
\hline Makan dan Minum & 3.08 & 2.17 \\
\hline
\end{tabular}




\begin{tabular}{lcc}
\hline \multicolumn{3}{c}{ Frekuensi aktivitas pemustaka di Perpustakaan } \\
\hline \multicolumn{1}{c}{ Aktivitas } & Mean & Standard deviation \\
\hline Pelatihan & 2.86 & 2.03 \\
\hline Menggunakan bahan audio visual & 2.75 & 1.85 \\
\hline Workshop atau seminar & 2.52 & 1.65 \\
\hline Berpartisipasi dalam event perpustakaan & 2.12 & 1.52 \\
\hline
\end{tabular}

Data diolah 2017

Responden menunjukkan belajar mandiri $(\mathrm{M}=5,23)$ sebagai aktivitas yang paling sering, diikuti dengan membaca $(M=5,17)$, penggunaan komputer $(M=5,11)$, menemukan informasi $(M=4,48)$, studi kelompok $(M=4,22)$, menggunakan referensi dan layanan informasi $(M=3,75)$, dan pertemuan dan bersosialisasi $(M=3,51)$. Aktivitas pemustaka dengan sarana yang relatif rendah mencakup sirkulasi $(M=3,42)$, makan dan minum $(M=3,08)$, pelatihan $(M=2,86)$, menggunakan materi audiovisual $(M=2,52)$, lokakarya dan seminar $(M=2,52)$, dan berpartisipasi dalam event perpustakaan $(M=$ 2.22). Analisis korelasi Spearman dilakukan untuk mengeksplorasi apakah pola penggunaan ulang perpustakaan tersebut berkorelasi dengan frekuensi setiap aktivitas. Hasil dari analisis korelasi menunjukkan frekuensi kunjungan perpustakaan memiliki korelasi positif yang signifikan dengan studi individual $(\mathrm{r}=0,36, \mathrm{pb} 0,01)$, kelompok belajar $(\mathrm{r}=0,29, \mathrm{pb} 0,01)$, membaca $(\mathrm{r}=0,26$, $\mathrm{Pb} 0,01)$, dan penggunaan komputer $(\mathrm{r}=0,17, \mathrm{pb} 0,05)$, menyiratkan bahwa pemustaka yang cenderung sering berkunjung ke perpustakaan. Rata-rata frekuensi setiap kunjungan ke perpustakaan memiliki korelasi positif yang signifikan dengan membaca $(r=0,40, \mathrm{pb} 0,01)$, belajar mandiri $(\mathrm{r}=0,39, \mathrm{pb}$ $0,01)$, makan dan minum $(\mathrm{r}=0,29$, pb 0,01), pelatihan $(\mathrm{r}=0,29, \mathrm{pb} 0,01)$, dan penggunaan komputer $(\mathrm{r}=0,19, \mathrm{pb} 0,05)$, hal ini menggambarkan bahwa pemustaka yang tinggal lebih lama di perpustakaan pada setiap kunjungan cenderung melakukan aktivitas ini lebih sering. Frekuensi kunjungan situs perpustakaan memiliki korelasi positif yang signifikan dengan menggunakan layanan referensi dan informasi $(\mathrm{r}=0,30, \mathrm{pb} 0,01)$, sirkulasi $(\mathrm{r}=0,25, \mathrm{pb}$ $0,01)$, dan belajar $(\mathrm{r}=0,20, \mathrm{pb} 0,05)$, menunjukkan bahwa pemustaka yang mengunjungi situs web perpustakaan cenderung lebih sering. 


\section{Persepsi Pemustaka Perpustakaan Perguruan Tinggi}

Mengenai persepsi pemustaka perpustakaan perguruan tinggi, responden studi diminta untuk menunjukkan tempat yang mereka anggap sebagai perpustakaan universitas. Hasil penelitian menunjukkan bahwa responden menganggap perpustakaan universitas sebagai tempat belajar $(\mathrm{M}=$ $6,27)$ dan pencarian informasi $(M=6,26)$. Skor rata-rata untuk perpustakaan menjadi tempat kontemplasi $(\mathrm{M}=4,94)$ dan tempat untuk pertemuan dan sosialisasi $(M=3,70)$ relatif tinggi, sedangkan skor rata-rata untuk tempat rekreasi relatif rendah $(\mathrm{M}=2,90)$.

Untuk mengeksplorasi hubungan antara pola penggunaan responden dan persepsi pemustaka terhadap perpustakaan akademik, dilakukan analisis korelasi Spearman. Sebuah korelasi positif yang signifikan ditemukan antara frekuensi kunjungan perpustakaan dan persepsi pemustaka a perpustakaan sebagai tempat belajar ( $\mathrm{r}=0,21, \mathrm{p}$ b 0,05). Hal ini menunjukkan bahwa pemustaka yang sering berkunjung ke perpustakaan cenderung lebih menganggap perpustakaan sebagai tempat belajar. Juga ditemukan bahwa ada korelasi positif yang signifikan antara frekuensi rata-rata setiap kunjungan dan persepsi pemustaka perpustakaan sebagai tempat belajar $(r=0,29, \mathrm{p}$ b 0,01). Ini menunjukkan bahwa pemustaka yang tinggal lebih lama ratarata pada setiap kunjungan ke perpustakaan lebih cenderung menganggap perpustakaan sebagai tempat belajar.

\section{Pembahasan}

Temuan penelitian ini menunjukkan bahwa perpustakaan perguruan tinggi merupakan tempat untuk belajar dan menghabiskan waktu di masa tidak ada perkuliahan di kampus. Hal ini mendukung temuan penelitian lain yang mengidentifikasi tempat favorit mahasiswa. Houlihan ${ }^{22}$ (2005) menunjukkan bahwa perpustakaan menjadi tempat yang lebih populer untuk bekerja dan bersosialisasi, terutama dan mengijinkan pemustaka membawa

${ }^{22}$ Houlihan, R. (2005). The academic library as congenial space: More on the Saint Mary's experience. New Library World, 106(1208/1209), 7-15. 
makanan dan minuman di dalam perpustakaan. Waxman, Clemons, Banning, dan McKelfresh ${ }^{23}$ (2007) menemukan bahwa perpustakaan merupakan tempat yang populer untuk bertemu dengan sesama mahasiswa, mengerjakan tugas kelompok, atau menemukan relaksasi dan menenangkan diri. Dalam sebuah penelitian yang menyelidiki pemanfaatan ruang di perpustakaan akademis, Bryant, Matthews, dan Walton ${ }^{24}$ (2009) melaporkan bahwa mahasiswa cenderung melakukan tugas-tugas akademik dan kegiatan sosial secara bersamaan. Ruang terbuka perpustakaan yang mendukung aktivitas akademis dan sosial ditemukan sebagai daerah yang populer.

Dalam penelitian ini, frekuensi kunjungan perpustakaan ditemukan secara signifikan dan berkorelasi positif dengan masa waktu rata-rata setiap kunjungan ke perpustakaan. Hasilnya menunjukkan bahwa pemustaka yang mengunjungi perpustakaan lebih sering cenderung tinggal lebih lama di setiap kunjungan. Selain itu, ditemukan bahwa frekuensi kunjungan perpustakaan secara signifikan dan berkorelasi positif dengan frekuensi kunjungan situs web perpustakaan. Ini menunjukkan bahwa pemustaka yang sering mengunjungi perpustakaan secara fisik dan cenderung mengunjungi situs web perpustakaan sesering mungkin. Namun, tidak ada korelasi yang signifikan antara waktu rata-rata setiap kunjungan ke perpustakaan secara fisik dan frekuensi kunjungan situs web perpustakaan.

Aktivitas pemustaka yang paling sering di perpustakaan ditemukan sebagai belajar mandiri, diikuti dengan urutan menurun dengan membaca, penggunaan komputer, menemukan informasi, studi kelompok, menggunakan layanan referensi dan informasi, dan pertemuan dan sosialisasi. Hasilnya konsisten dengan penelitian lain yang melaporkan bahwa ruang belajar merupakan ruang yang paling sering digunakan di perpustakaan

${ }^{23}$ Waxman, L., Clemons, S., Banning, J., \& McKelfresh, D. (2007). The library as place: Provid- ing students with opportunities for socialization, relaxation, and restoration. New Library World, 108, 424-434.

${ }^{24}$ Bryant, J., Matthews, G., \& Walton, G. (2009). Academic libraries and social and learning space: A case study of Loughborough University Library, UK. Journal of Librarianship and Information Science, 41, 7-18. 
akademik. King, Buss, Cohen, Stanley, Dan White ${ }^{25}$ (2008) menekankan pentingnya ruang belajar bahwa ruang yang paling umum digunakan di perpustakaan yaitu ruang untuk belajar mandiri dan kelompok. Laporan kecenderungan penggunaan perpustakaan oleh mahasiswa, Lawson ${ }^{26}(2004)$ mencatat bahwa banyak digunakan perpustakaan universitas sebagai tempat belajar secara individu atau berkelompok. Dengan demikian, perpustakaan akademik perlu menyediakan berbagai ruang belajar yang memenuhi gaya belajar dan preferensi ruang pemustaka. Membaca juga merupakan tujuan utama untuk datang ke perpustakaan akademik. Freeman ${ }^{27}$ (2005) mencatat bahwa banyak mahasiswa menganggap ruang baca tradisional sebagai area favorit perpustakaan mereka. Penggunaan komputer publik masih kuat di perpustakaan, dan meningkatkan jumlah komputer dan periferal (Lux, Snyder, \& Boff ${ }^{28}, 2016$; Whitmire $\left.{ }^{29}, 2001\right)$. Menemukan informasi juga dilaporkan sebagai kegiatan yang sering dilakukan di perpustakaan. Nilai rata-rata untuk aktivitas pemustaka seperti pemanfaatan layanan referensi dan informasi dan pertemuan dan sosialisasi juga ditemukan relatif tinggi, sehingga menyiratkan pentingnya penyediaan layanan perpustakaan yang efektif dan lingkungan yang ramah yang memperkaya pengalaman sosial pemustaka. Memperoleh hubungan antara pola pemanfaatan dan aktivitas pemustaka di perpustakaan, frekuensi kunjungan ke perpustakaan memiliki korelasi positif yang signifikan dengan belajar mandiri, studi kelompok, belajar, dan penggunaan komputer. Ini menyiratkan bahwa pemustaka yang sering berkunjung ke perpustakaan cenderung melakukan

${ }^{25}$ King, F. E., Buss, C. W., Cohen, N., Stanley, D., \& White, E. (2008). The University of Georgia students learning center. In P. Hernon, \& R. R. Powell (Eds.), Convergence and collab- oration of campus information services (pp. 125-139). Westport, CT: Libraries Unlimited.

${ }^{26}$ Lawson, K. (2004). Libraries in the USA as traditional and virtual "third places." New

Library World, 105(1198/1199), 125-130.

${ }^{27}$ Freeman, G. T. (2005). The library as place: Changes in learning patterns, collections, tech- nology, and use. Library as place: Rethinking roles, rethinking space (pp. 1-9). Wash- ington, D.C.: Council on Library and Information Resources.

${ }^{28}$ Lux, V. J., Snyder, R. J., \& Boff, C. (2016). Why users come to the library: A case study of library and non-library units. Journal of Academic Librarianship, 42, 109-117.

${ }^{29}$ Whitmire, E. (2001). A longitudinal study of undergraduates' academic library experiences. Journal of Academic Librarianship, 27, 379-385. 
aktivitas seperti studi individual, studi kelompok, belajar, dan penggunaan komputer lebih sering dilakukan. Perpustakaan akademik perlu memperluas fasilitas dan layanannya untuk mendukung kegiatan agar menarik lebih banyak pemustaka ke perpustakaan. Waktu rata-rata setiap kunjungan ke perpustakaan memiliki korelasi positif yang signifikan dengan belajar secara individu, diijinkan makan dan minum, menggunakan ruang, dan penggunaan komputer. Ini menunjukkan bahwa pemustaka yang tinggal lebih lama di perpustakaan pada setiap kunjungan cenderung terlibat dalam aktivitas ini menjadi lebih sering. Mengingat bahwa pemustaka yang terlibat dalam kegiatan semacam itu cenderung tinggal lebih lama di perpustakaan, perpustakaan perlu menciptakan lingkungan yang nyaman dan efisien untuk mendukung kegiatan tersebut. Selain itu, frekuensi kunjungan situs perpustakaan memiliki korelasi positif yang signifikan dengan menggunakan layanan referensi dan informasi, sirkulasi, dan belajar. Ini menunjukkan bahwa pemustaka yang mengunjungi situs web perpustakaan seringkali cenderung terlibat dalam aktivitas seperti lebih sering menggunakan layanan referensi dan informasi, sirkulasi, dan belajar. Dengan adanya korelasi tidak nonsignifikan antara frekuensi kunjungan situs perpustakaan dan rata-rata lama setiap kunjungan ke perpustakaan, pengunjung situs web yang sering tidak lama berkunjung di perpustakaan perlu diberi layanan efisien dan efisien saat mereka mengunjungi perpustakaan.

Mengenai persepsi pemustaka perpustakaan universitas, temuan penelitian ini menunjukkan bahwa pemustaka memandang perpustakaan terutama sebagai tempat belajar dan pencarian informasi. Karena pembelajaran di bidang pendidikan tinggi menekankan interaksi dan diskusi kelompok yang memungkinkan mahasiswa untuk menemukan dan berbagi pengetahuan dengan peserta didik lainnya (Sens, 2009), perpustakaan perlu mendukung aspek sosial dan kolaboratif proses belajar mahasiswa dengan membentuk kembali ruang belajar. Mengakomodasi pendekatan baru untuk belajar dan berbagai gaya belajar pemustaka, perpustakaan harus melakukan upaya untuk membentuk kembali ruang perpustakaan yang sesuai dengan kebutuhan pemustaka khususnya tren generasi saat ini. Seiring dengan 
berkembangnya ruang dan fasilitas, penyediaan informasi dan pelayanan sangat penting di perpustakaan untuk meningkatkan pembelajaran. Ini mungkin termasuk penyediaan koleksi cetak dan digital yang memenuhi persyaratan kualitas informasi dan preferensi pemustaka, menyiapkan pelatihan akses sumber informasi, dan pengelolaan tugas akhir mahasiswa yang efektif untuk pengetahuan komunitas akademik. Sebagai tempat mencari informasi, perpustakaan akademis perlu menyediakan layanan dan program informasi enterprenurship yang efektif yang memfasilitasi kegiatan belajar dan pengetahuan dari komunitas akademis. Kegiatan enterprenurship diberikan pada event tertentu seperti workshop yang melibatkan perpustakaan, pustakawan dan mahasiswa dalam berbagi pengalaman dengan pengusaha muda dalam hal ini mahasiswa. Selain itu, nilai rata-rata untuk persepsi pengguna perpustakaan akademik sebagai tempat perenungan dan tempat untuk bertemu dan bersosialisasi juga tergolong tinggi, menyiratkan bahwa perpustakaan dianggap sebagai tujuan multi tujuan yang diharapkan dapat melayani berbagai fungsi yang mencakup berbagai aktivitas pemustaka.

\section{Kesimpulan}

Penelitian ini memberikan bukti empiris persepsi pemustaka dan pemanfaatan fasilitas perpustakaan perguruan tinggi. Ini menunjukkan bahwa perpustakaan merupakan tempat yang disukai untuk tempat belajar dan menghabiskan waktu di kampus. Ditemukan bahwa aktivitas pemustaka sering dilakukan di perpustakaan termasuk belajar mandiri, membaca, penggunaan komputer, mencari dan menemukan informasi, studi kelompok/ diskusi, menggunakan referensi dan layanan informasi, dan pertemuan dan sosialisasi. Pemustaka cenderung menganggap perpustakaan sebagai tempat belajar dan pencarian informasi. Persepsi pemustaka perpustakaan akademik sebagai tempat perenungan dan tempat untuk pertemuan dan bersosialisasi ditemukan relatif tinggi, menyiratkan harapan pemustaka akan perpustakaan sebagai tujuan multi guna yang mendukung berbagai aktivitas pemustaka. Mengingat pentingnya pembelajaran dan pencarian informasi yang teridentifikasi dalam persepsi pemustaka, maka perpustakaan perlu 
mengakomodasi ruang pemustaka untuk ruang belajar dan memberikan layanan dan program informasi yang efektif. Untuk tetap menjadi tempat yang bernilai bagi komunitas akademis, perpustakaan harus berkembang menjadi tempat yang menarik untuk mendukung berbagai aktivitas pemustaka dengan terus mereformasi fasilitas dan layanan yang tersedia. Kegiatan enterprenurship diberikan pada event tertentu seperti workshop sharing informasi berbagi pengalaman dengan pengusaha muda dalam hal ini mahasiswa. Temuan penelitian ini menunjukkan bagaimana pemustaka di perguruan tinggi saat ini memandang perpustakaan akademis dan bagaimana menggunakan ruang dan layanan perpustakaan. Pemustaka dapat memberikan wawasan tentang bagaimana perpustakaan dapat memperkuat dan memajukan peran mereka di komunitas akademis.

\section{Daftar Pustaka}

Albanese, A. R. Deserted no more. Library Journal, 128, 34-36. 2003.

Allison, D. Measuring the academic impact of libraries. Portal: Libraries and the Academy, 15, 29-40. 2015.

Applegate, R. The library is for studying: Student preferences for study space. Journal of Academic Librarianship, 35, 341-346. 2009.

Bridges, L. M. Who is not using the library? A comparison of undergraduate aca- demic disciplines and library use. Portal: Libraries and the Academy, 8, 187-196. 2008.

Bryant, J., Matthews, G., \& Walton, G. Academic libraries and social and learning space: A case study of Loughborough University Library, UK. Journal of Librarianship and Information Science, 41, 7-18. 2009.

de Jager, K. Library use and academic achievement. South African Journal of Library \& Information Science, 65, 26-30. 1997.

Freeman, G. T. The library as place: Changes in learning patterns, collections, tech-nology, and use. Library as place: Rethinking roles, rethinking space (pp. 1-9). 2005. Washington, D.C.: Council on Library and Information Resources. 
Given, L. M. Setting the stage for undergraduates' information behaviors: Faculty and librarians' perspectives on academic space. In J. E. Buschman, \& G. J. Leckie (Eds.), The library as place: History, community, and culture (pp. 177-190). 2007. Westport, CT: Libraries Unlimited.

Hall, K., \& Kapa, D.Silent and independent: Student use of academic library study space. Canadian Journal of Library and Information Practice and Research, 10(1), 1-38. 2015.

Houlihan, R.The academic library as congenial space: More on the Saint Mary's experience. New Library World, 106(1208/1209), 7-15. 2005.

King, F. E., Buss, C. W., Cohen, N., Stanley, D., \& White, E. The University of Georgia students learning center. In P. Hernon, \& R. R. Powell (Eds.), Convergence and collab- oration of campus information services (pp. 125-139). 2008. Westport, CT: Libraries Unlimited.

Lawson, K. Libraries in the USA as traditional and virtual "third places.. New Library World, 105(1198/1199), 125-130. 2004

Lux, V. J., Snyder, R. J., \& Boff, C. Why users come to the library: A case study of library and non-library units. Journal of Academic Librarianship, 42, 109-117. 2016.

Martell, C. The absent user: Physical use of academic library collections and services continues to decline 1995-2006. Journal of Academic Librarianship, 34, 400-407. 2008.

McKay, D. Spinning straw into gold: A community college library's twenty first century transformation. Community \& Junior College Libraries, 17, 1-6. 2011.

Peterson, C. A.Space designed for lifelong learning: The Dr. Martin Luther King Jr.Joint-use Library. Library as place: Rethinking roles, rethinking space (pp. 56-65). 2005. Washington, D.C.: Council on Library and Information Resources.

Sens, T. Twelve keys to library design: Improving the academic experience. Library Journal, 34. 2009. 
Shill, H. B., \& Tonner, S. Does the building still matter? Usage patterns in new, ex- panded, and renovated libraries, 1995-2002. College \& Research Libraries, 65, 123-150. 2004.

Soria, K. M., Fransen, J., \& Nackerud, S. Stacks, serials, search engines, and stu- dents' success: First-year undergraduate students' library use, academic achieve- ment, and retention. Journal of Academic Librarianship, 40, 84-91.2014.

Soria, K. M., Nackerud, S., \& Peterson, K. Socioeconomic indicators associated with first-year college students' use of academic libraries. Journal of Academic Librarianship, 41, 636-643. 2015.

Suciati, Uminurida. Evaluasi pemanfaatan fasilitas belajar ruang diskusi tahun 2015. Yogyakarta: Perpustakaan UGM, 2015.

Suciati, Uminurida. Evaluasi pemanfaatan fasilitas belajar ruang diskusi tahun 2016. Yogyakarta: Perpustakaan UGM, 2016.

Suciati, Uminurida; Nurhayati; Widayati, Preferensi Pemustaka dalam Menyusun Tugas Akhir (skripsi/Tesis/Disertasi) Menggunakan Sumber Informasi Database Online (studi kasus di Perpustakaan Fakultas Filsafat UGM), Berkala Ilmu Perpustakaan dan Informasi Vol. 7 no 1 tahun 2012, Perpustakaan UGM.

Waxman, L., Clemons, S., Banning, J., \& McKelfresh, D. The library as place: Provid- ing students with opportunities for socialization, relaxation, and restoration. New Library World, 108, 424-434.2007.

Whitmire, E. A longitudinal study of undergraduates' academic library experi- ences. Journal of Academic Librarianship, 27, 379-385.2001.

Whitmire, E. Cultural diversity and undergraduates' academic library use. Journal of Academic Librarianship, 29, 148-161. 2003.

Wong, S. H. R., \& Webb, T. D. Uncovering meaningful correlation between student academic performance and library material usage. College \& Research Libraries, 72, 361-370. 2011. 